\title{
Q fever in humans and farm animals in four European countries, 1982 to 2010
}

M Georgiev (mgeorgiev@rvc.ac.uk) ${ }^{1}$, A Afonso ${ }^{2}$, H Neubauer 3 , Howard Needham ${ }^{4}$, R Thiéry5 , A Rodolakis ${ }^{6}$, H J Roest 7 , K D Stärk ${ }^{8}$, J A Stegeman', P Vellema $^{10}$, W van der Hoek ${ }^{11}$, S J More ${ }^{12}$

1. Royal Veterinary College (RVC), London, United Kingdom

2. European Food Safety Authority (EFSA), Parma, Italy

3. Friedrich-Loeffler-Institute, Institute for Bacterial Infections and Zoonoses, Jena, Germany

4. European Centre for Disease Prevention and Control (ECDC), Stockholm, Sweden

5. ANSES, Laboratoire de Sophia-Antipolis, Unité pathologie des ruminants, Sophia-Antipolis, France

6. Institut National de la Recherche Agronomique (INRA), Ur1282 Infectiologie Animale et Santé Publique, Nouzilly, France

7. Department of Bacteriology and TSEs, Central Veterinary Institute, part of Wageningen UR, Lelystad, Netherlands

8. SAFOSO, Safe Food Solutions Inc., Bern, Switzerland

9. University of Utrecht, Dept. Farm Animal Health, Utrecht, the Netherlands

10. Department of Small Ruminant Health, Animal Health Service GD Deventer, Deventer, Netherlands

11. Centre for Infectious Disease Control, National Institute for Public Health and the Environment, Bilthoven, Netherlands

12. Centre for Veterinary Epidemiology and Risk Analysis, UCD School of Veterinary Medicine, University College Dublin, Belfield, Dublin 4, Ireland

Citation style for this article:

Georgiev M, Afonso A, Neubauer H, Needham H, Thiéry R, Rodolakis A, Roest HJ, Stärk KD, Stegeman JA, Vellema P, van der Hoek W, More SJ. Q fever in humans and farm animals in four European countries, 1982 to 2010. Euro Surveill. 2013;18(8):pii=20407. Available online: http://www.eurosurveillance.org/ViewArticle. aspx?Articleld $=20407$

Article submitted on 20 April 2012 / published on 21 February 2013

$Q$ fever is a disease of humans, caused by Coxiella burnetii, and a large range of animals can be infected. This paper presents a review of the epidemiology of $Q$ fever in humans and farm animals between 1982 and 2010, using case studies from four European countries (Bulgaria, France, Germany and the Netherlands). The Netherlands had a large outbreak between 2007 and 2010, and the other countries a history of $Q$ fever and $Q$ fever research. Within all four countries, the serological prevalence of $C$. burnetii infection and reported incidence of $Q$ fever varies broadly in both farm animals and humans. Proximity to farm animals and contact with infected animals or their birth products have been identified as the most important risk factors for human disease. Intrinsic farm factors, such as production systems and management, influence the number of outbreaks in an area. A number of disease control options have been used in these four countries, including measures to increase diagnostic accuracy and general awareness, and actions to reduce spillover (of infection from farm animals to humans) and human exposure. This study highlights gaps in knowledge, and future research needs.

\section{Introduction}

$Q$ fever is a disease of humans [1,2]. The aetiological agent, Coxiella burnetii, is a Gram-negative and obligate intracellular bacterium. C. burnetti has also been isolated from a large range of animals including farm animals (e.g. cattle, sheep and goats), wildlife and arthropods [3]. It has a near worldwide distribution.

The febrile illness 'Query fever' ( $Q$ fever) was first reported in 1935, among workers in slaughterhouses in Australia [4]. Initial hypotheses about potential exposures and infectious pathways emerged following the development of illness in experimental animals (guinea pigs) via feeding of ticks [5] collected from febrile livestock in Nine Mile, United States. Investigations into cases of atypical pneumonia subsequently revealed the importance of aerosol transmission. Epidemiological linkages with animals were later identified, and infection was found in a broad range of hosts $[1,3]$. It was initially thought that $Q$ fever was primarily an occupational risk (for people who worked closely with animals) however this was subsequently expanded, with risk groups also including people with a specific health status (pregnancy, cardiac diseases, immune-compromised). Blood donation was identified as a potential source of infection.

In Europe, cases of $Q$ fever in humans were first reported from soldiers in the Balkan region including Bulgaria in 1940 [6], and subsequently in Germany shortly after World War II [2], and in the Netherlands in 1956 [7].

The course of human infection ranges from asymptomatic to severe, but typically results in a mild, self-limiting, influenza-like disease (acute infection). However, some patients develop a more serious chronic infection, including endocarditis and other complicated infections (e.g. vascular or osteoarticular infections). Infection by $C$. burnetti in pregnancy can also result in spontaneous abortion, premature delivery, low birth weight and the development of chronic C. burnetti infection [8]. The European Union (EU) harmonised $Q$ fever case definition, in use since the year 2003, includes clinical (any person with at least one of the following three symptoms: fever, pneumonia, hepatitis), 
laboratory (at least one of the following three diagnostic findings: isolation of $C$. burnetii from a clinical specimen, detection of $C$. burnetii nucleic acid in a clinical specimen, $C$. burnetii specific antibody response (IgG or IgM phase II)) and epidemiological (at least one of the following two epidemiological links: exposure to a common source, animal-to-human transmission) criteria [9].

In domestic ruminants, as in people, C. burnetti infection and $\mathrm{Q}$ fever (the disease) are not the same. C. burnetti infection is usually subclinical (i.e. the animal is infected with $C$. burnetii but without clinical signs). Q fever, which develops in a subset of infected animals, presents as late abortion and reproductive disorders $[1,2,10,11]$. A definitive diagnosis of $Q$ fever in animals is based on the observation of the occurrence of abortions and/or stillbirths, confirmation of the presence of the aetiological agent (i.e. polymerase chain reaction $(P C R)$, isolation, staining, immunofluorescence assay tests are positive) and positive serological findings in the herd [12].

Q fever has generally been associated with transient outbreaks in animals and humans, and sporadic human cases. Prompted by the outbreak of $Q$ fever in the Netherlands that occurred from 2007 to 2010, concerns were raised by the European Commission about factors contributing to the development of large, sustained Q fever outbreaks [2]. The Dutch outbreak was considered to be the largest community outbreak ever recorded $[2,13,14]$, with 4,026 human cases notified between 2007 and 2010 [15-17].

This paper presents a descriptive analysis, comparison and critical appraisal of the epidemiology of $Q$ fever in humans and farm animals, including modes of transmission and control measures, using case studies from four European countries: Bulgaria, France, Germany and the Netherlands.

\section{Methods}

This study was conducted as a review of $Q$ fever epidemiology in four European countries. These countries were chosen by experts of a working group of the European Food Safety Authority (EFSA) [2]. The EFSA working group comprised a group of scientists with specialised knowledge and experience on $Q$ feverrelated issues, who were assembled to collectively formulate a response to a range of risk-related questions posed by the European Commission. The four countries were chosen based on the following rationale: the Netherlands experienced a large $Q$ fever outbreak between 2007 and 2010, France and Germany are countries in proximity to the Netherlands where $Q$ fever is endemic and where a considerable number of relevant scientific data and publications are available, and Bulgaria is a country with both a long history of $Q$ fever and, as in the Netherlands, with substantial changes in husbandry systems over time. For each of these four countries, information was collected on $Q$ fever in humans and farm animals based on a detailed review of relevant peer reviewed and non-peer reviewed literature. Relevant literature was identified following interrogation of two publication databases, ISI Web of Knowledge and PubMed, using defined qualifiers for infection and disease (C. burnetii infection, $Q$ fever), host (humans, farm animals), location (Bulgaria, France, Germany and the Netherlands)) and issue (epidemiology, diagnostics, control, review). The search was limited to literature published from 2005 to 2010, but relating to the period from 1982 to 2010. Additional national literature (both peer reviewed and non-peer reviewed) was obtained by working group members, and complemented with their expert knowledge and opinion, noting that EFSA working group included national experts on these issues from Bulgaria, France, Germany and the Netherlands [2]. Screening of published material was initially conducted by two reviewers of the working group, based on title and abstract, leading, if relevant to the above-mentioned qualifiers, to retrieval of the full paper for consideration in the current review and details available elsewhere [2]. A descriptive analysis was subsequently conducted.

\section{Results}

A total of 110 papers were retrieved, based on title and abstract, with 22 being retained, following further evaluation, for the current review.

\section{Farm animals}

Seroprevalence

The serological prevalence of $C$. burnetii infection in farm animals varies by host species, geographic area and time (Table 1), whereby it also should be noted that different serological cut-offs were used in different studies. Within-herd prevalence estimates for cattle were up to $20.8 \%$ in Bulgaria, $15.0 \%$ in France, $19.3 \%$ in Germany, $21.0 \%$ in the Netherlands, for goats up to 40.0\% in Bulgaria, $88.1 \%$ in France, $2.5 \%$ in Germany, $7.8 \%$ in the Netherlands, and for sheep up to $56.9 \%$ in Bulgaria, $20.0 \%$ in France, $8.7 \%$ in Germany, 3.5\% in the Netherlands respectively. Herd prevalence estimates, whereby a herd is considered positive when at least one animal in the herd was serologicallyconfirmed, were higher than within-herd prevalence. Herd prevalence for cattle was up to $73.0 \%$, in France, and up to $37.0 \%$ in the Netherlands. For goats it was $40.0 \%$ in France and $17.8 \%$ in the Netherlands while for sheep values of $89.0 \%$ in France, and $14.5 \%$ in the Netherlands were respectively found. Regional differences were observed: up to four-fold among farm animals in different areas of Bulgaria [18], and higher in some rural German regions [19-21].

\section{Clinical disease}

Estimating the $Q$ fever incidence in farm animals is difficult, due to the non-specific nature of disease on the one hand and the multifactorial nature of abortion on the other. Further, it is uncommon for detailed veterinary investigations to occur, including efforts towards 
TABLE 1

Estimated prevalence of Coxiella burnetii infection in farm animals, based on studies conducted in Bulgaria, France, Germany and the Netherlands, 1982-2010

\begin{tabular}{|c|c|c|c|c|c|c|c|}
\hline \multirow{2}{*}{ Country } & \multirow{2}{*}{ Year of study } & \multicolumn{2}{|c|}{ Number tested } & \multicolumn{2}{|c|}{$\%$ positive } & \multirow{2}{*}{ Test } & \multirow{2}{*}{ Reference } \\
\hline & & Animals & Herds & Animals & Herds & & \\
\hline \multicolumn{8}{|l|}{ Cattle } \\
\hline$B G$ & $1977-1988$ & 20,086 & NA & 11.8 & NA & CFT & [23] \\
\hline$B G$ & $1989-2006$ & 95,737 & NA & 5.4 & NA & CFT & [23] \\
\hline$B G$ & 2002 & 3,006 & NA & 8.2 & NA & CFT & [23] \\
\hline$B G$ & 2003 & 3,714 & NA & 6.5 & NA & CFT & [23] \\
\hline$B G$ & 2004 & 120 & NA & $20.8^{a}$ & NA & IFA & [32] \\
\hline$B G$ & 2004 & 3,188 & NA & 9.7 & NA & CFT & [23] \\
\hline$B G$ & 2005 & 3,026 & NA & 8.1 & NA & CFT & [23] \\
\hline$B G$ & 2006 & 2,932 & NA & 10.6 & $\mathrm{NA}$ & CFT & [23] \\
\hline $\mathrm{DE}$ & 1991 & 1,095 & 21 & 11.8 & 81.0 & ELISA & [75] \\
\hline DE & 1992-1993 & $\begin{array}{c}500 \\
665 \\
383^{b} \\
612\end{array}$ & $\begin{array}{c}\text { NA } \\
39 \\
33 \\
1\end{array}$ & $\begin{array}{c}7.6 \\
9.6 \\
19.3 \\
5.6\end{array}$ & $\begin{array}{c}\text { NA } \\
76.9 \\
78.8 \\
100.0\end{array}$ & CFT & [76] \\
\hline $\mathrm{DE}$ & 1998 & 21,196 & 544 & 8.0 & NA & ELISA & {$[1]$} \\
\hline $\mathrm{DE}$ & $1996-1997$ & 826 & 38 & $14 \cdot 3^{b}$ & NA & ELISA & [77] \\
\hline $\mathrm{DE}$ & $1998-2000$ & 1,167 & 105 & $1.4-2.0^{b}$ & NA & ELISA & [78] \\
\hline FR & NA & NA & NA & $1.0-15.0$ & $39-73$ & NA & [79] \\
\hline $\mathrm{NL}$ & 1987 & $1,160^{b}$ & 234 & 21.0 & 37.0 & ELISA & [8o] \\
\hline $\mathrm{NL}$ & 2007 & $2,781^{c}$ & 341 & 16.0 & 78.6 & ELISA & [69] \\
\hline $\mathrm{NL}$ & 2007 & $2,781^{c}$ & 341 & 8.7 & 56.6 & PCR & [69] \\
\hline \multicolumn{8}{|l|}{ Goats } \\
\hline$B G$ & 2002 & 677 & NA & 11.8 & NA & CFT & [23] \\
\hline$B G$ & 2003 & 1,044 & NA & 7.4 & NA & CFT & [23] \\
\hline$B G$ & 2004 & 50 & NA & $40.0 a$ & NA & IFA & [32] \\
\hline$B G$ & 2004 & 1,016 & NA & 21.7 & NA & CFT & [23] \\
\hline$B G$ & 2005 & 832 & NA & 11.1 & NA & CFT & [23] \\
\hline$B G$ & 2006 & 359 & NA & 19.2 & NA & CFT & [23] \\
\hline$B G$ & $1950-1976$ & 1,417 & NA & 20.5 & NA & CFT & [23] \\
\hline$B G$ & $1977-1988$ & 1,791 & NA & 10.8 & NA & CFT & [23] \\
\hline$B G$ & $1989-2006$ & 54,175 & NA & 7.6 & $\mathrm{NA}$ & CFT & [23] \\
\hline FR & 2006 & 359 & NA & 36.0 & NA & ELISA & [81] \\
\hline FR & 2006 & NA & 42 & 88.1 & NA & ELISA & [81] \\
\hline FR & 2006 & 75 & NA & $65 \cdot 3^{b}$ & NA & ELISA & [82] \\
\hline $\mathrm{FR}$ & 2008 & 1,057 & NA & 32.0 & NA & ELISA & [81] \\
\hline FR & 2008 & 42 & NA & 88.1 & NA & ELISA & [81] \\
\hline FR & NA & NA & NA & $2.0-12.0$ & $10-40.0$ & NA & [79] \\
\hline $\mathrm{DE}$ & 1998 & 278 & NA & 2.5 & NA & ELISA & {$[1]$} \\
\hline $\mathrm{NL}$ & 1987 & 498 & NA & 1.0 & NA & ELISA & [8o] \\
\hline $\mathrm{NL}$ & 2008 & 3,409 & NA & 7.8 & NA & ELISA & [15] \\
\hline $\mathrm{NL}$ & 2008 & NA & NA & 7.8 & 17.8 & NA & [13] \\
\hline \multicolumn{8}{|l|}{ Sheep } \\
\hline$B G$ & 2002 & 1,819 & NA & 12.7 & NA & CFT & [23] \\
\hline$B G$ & 2003 & 1,811 & NA & 8.3 & NA & CFT & [23] \\
\hline$B G$ & 2004 & 100 & NA & $21.0 \mathrm{a}$ & NA & IFA & [32] \\
\hline$B G$ & 2004 & 1,258 & NA & 14.1 & NA & CFT & [23] \\
\hline$B G$ & 2005 & 1,911 & NA & 15.2 & NA & CFT & [23] \\
\hline$B G$ & 2006 & 1,925 & NA & 8.4 & NA & CFT & [23] \\
\hline$B G$ & $1950-1976$ & 17,088 & NA & 16.7 & NA & CFT & [23] \\
\hline$B G$ & $1977-1988$ & 16,593 & NA & 18.8 & NA & CFT & [23] \\
\hline$B G$ & $1989-2006$ & 99,189 & NA & 4.8 & NA & CFT & [23] \\
\hline$B G$ & NA-2006 & 153 & NA & $56.9^{b}$ & $\mathrm{NA}$ & CFT & [62] \\
\hline $\mathrm{DE}$ & NA & NA & 95 & NA & 2.7 & NA & [83] \\
\hline $\mathrm{DE}$ & $1983-1986$ & 4,337 & NA & $0.6-4.3$ & NA & CFT & [40] \\
\hline $\mathrm{DE}$ & 1998 & 1,346 & NA & 1.3 & NA & ELISA & [1] \\
\hline $\mathrm{DE}$ & 1999 & 100 & 1 & 57.0 & NA & ELISA & {$[1]$} \\
\hline $\mathrm{DE}$ & NA & 3,460 & NA & 8.7 & NA & ELISA & [84] \\
\hline FR & NA & NA & NA & $0-20.0$ & $0-89.0$ & NA & [79] \\
\hline $\mathrm{NL}$ & 1987 & 3,603 & NA & 3.5 & NA & ELISA & [8o] \\
\hline $\mathrm{NL}$ & 2008 & 12,363 & NA & 2.4 & NA & ELISA & {$[15]$} \\
\hline $\mathrm{NL}$ & 2008 & NA & NA & 2.4 & 14.5 & NA & [13] \\
\hline
\end{tabular}

BG: Bulgaria; CFT: complement fixation test; DE: Germany; ELISA: enzyme-linked immunosorbent assay; FR: France; IFA: indirect immunofluorescence assay; NA: information not available or not specified; NL: Netherlands; PCR: polymerase chain reaction.

a Investigation in relation to a human outbreak.

b Investigation in relation to clinical signs in the animal population.

c Lactating cows. 
TABLE 2

Estimated prevalence of Coxiella burnetii infection in people, based on studies conducted in Bulgaria, France, Germany and the Netherlands, 1982-2010

\begin{tabular}{|c|c|c|c|c|c|c|}
\hline Country & Year of study & Number tested & Sample group & $\%$ positive & Test & Reference \\
\hline$B G$ & $1993-2000$ & 14,353 & RG & 15.0 & CFT, MIFT & [23] \\
\hline$B G$ & $1995-1997$ & 224 & $\mathrm{BD}$ & 38.0 & MAT, MIFT & [29] \\
\hline BG & $2001-2004$ & 5,207 & $R G$ & 18.0 & CFT, MIFT & [23] \\
\hline$B G$ & 2004 & 104 & $\mathrm{HO}(\mathrm{PW})$ & 7.7 & IFA & [32] \\
\hline $\mathrm{DE}$ & 2002 & 255 & $\mathrm{HO}$ & 22.0 & NA & [78] \\
\hline $\mathrm{FR}$ & $1982-1990$ & 22,496 & RG & 23.0 & NA & [8] \\
\hline $\mathrm{FR}$ & 1988 & 924 & $\mathrm{BD}$ & 4.0 & IFA & {$[85]$} \\
\hline $\mathrm{FR}$ & 1995 & 790 & $\mathrm{BD}$ & 1.0 & IFA & [1] \\
\hline $\mathrm{FR}$ & $1995-1996$ & 785 & NA & 5.0 & IFA & [1] \\
\hline FR & 1996 & 620 & $\mathrm{BD}$ & 3.0 & IFA & [1] \\
\hline$F R$ & 1996 & 12,716 & NA & 0.2 & IFA & [1] \\
\hline $\mathrm{FR}$ & 1996 & 208 & $R G$ & 71.0 & IFA & [86] \\
\hline $\mathrm{FR}$ & $2002-2003$ & 376 & RG (PW) & 2.6 & IFA & [87] \\
\hline $\mathrm{FR}$ & $2002-2003$ & 91 & RG (CA) & 5.5 & IFA & [87] \\
\hline $\mathrm{FR}$ & $2002-2003$ & 578 & $\mathrm{HO}$ & 14.7 & IFA & [87] \\
\hline $\mathrm{NL}$ & 1982 & 222 & RG & 83.8 & NA & [88] \\
\hline $\mathrm{NL}$ & 1983 & 359 & $\mathrm{BD}$ & 24.0 & NA & [88] \\
\hline $\mathrm{NL}$ & $2006-2007$ & 5,654 & GP & 2.4 & ELISA, IFA & [89] \\
\hline $\mathrm{NL}$ & 2007-2009 & 2,004 & $\mathrm{HO}(\mathrm{PW})$ & 9.1 & IFA & [90] \\
\hline $\mathrm{NL}$ & 2009 & 543 & $\mathrm{BD}$ & 12.2 & ELISA, IFA & [91] \\
\hline
\end{tabular}

BD: blood donors; BG: Bulgaria; CA: cardiac abnormalities; CFT: complement fixation test; DE: Germany; ELISA: enzyme-linked

immunosorbent assay; FR: France; GP: general population; HO: humans in outbreak areas; IFA: indirect immunofluorescence assay; MAT:

microagglutination test; MIFT: microimmunofluorescence test; NA: information not available or not specified; NL: Netherlands; PW: pregnant women; RG: risk group.

laboratory confirmation of the causative agent, following a single abortion in a herd or flock. During the outbreak in the Netherlands between 2007 and 2010, an average of $20 \%$ (range of $10-80 \%$ ) of pregnant goats aborted on affected farms. On two affected sheep farms in the Netherlands, the estimated abortion rate was $5 \%[13,15]$. From 0.5 to $3.8 \%$ of abortions in cattle were attributed to $C$. burnetii in surveys in Germany during the period from 1993 to 1996 [2]. Clinical disease (with abortions attributed to $C$. burnetii infection) in five of 21 goat flocks were observed over five years in Deux-Sevres, France [22]. The disease is well recognised among the veterinary community in all four countries, and it has been notifiable in dairy sheep and goats at EU level in Bulgaria, Germany and the Netherlands since 2008. This was not the case in France [2], which may have an influence on the number of cases being reported.

\section{Humans}

\section{Seroprevalence}

Estimates of prevalence of $C$. burnetii infection, based on serological studies conducted in the four countries since 1982, are presented in Table 2. It should be noted that different serological cut-offs were used in different studies. There is large variability in the overall seroprevalence in the sampled population groups: in the general population, $2.4 \%$ in the Netherlands; among blood donors, 1.0 to $4.0 \%$ in France, 12.2 to $\mathbf{2 4 . 0 \%}$ in the Netherlands, $22.0 \%$ in Germany and $38.0 \%$ in Bulgaria; in risk groups 15.0 to $18.0 \%$ in Bulgaria (patients presenting with atypical pneumonia and cardio-vascular diseases), 2.6 to $71.0 \%$ in France (pregnant woman, patients with cardiac diseases, persons involved in goat breeding, veterinarians; seroprevalence was highest among the latter two groups), $83.8 \%$ in the Netherlands (veterinarians dealing with livestock); in humans in outbreak areas, $7.7 \%$ in Bulgaria (pregnant women), 9.1\% in the Netherlands (pregnant women), $14.7 \%$ in France (post epidemic surveillance in outbreak areas among people not considered at higher than normal risk) and $\mathbf{2 2 . 0 \%}$ in Germany (farmers whose livestock experienced abortions).

\section{Clinical disease}

In all four countries, Q fever varies considerably in terms of geographic distribution, case numbers and clinical presentation. Disease was notifiable in humans at the national level throughout the full study period (1982-2010) in Bulgaria, Germany and the Netherlands and not in France. Since 2000, Q fever in humans must be monitored and notified within the EU, as required under EU legislation (Commission Decision 2000/96/ 
TABLE 3

Reported Q fever outbreaks in the human population in Bulgaria, France, Germany and the Netherlands, 1982-2010

\begin{tabular}{|c|c|c|c|c|c|}
\hline Country: region & Year & Most likely source & Number of cases & $\begin{array}{l}\text { Laboratory } \\
\text { diagnosis }\end{array}$ & Reference(s) \\
\hline DE (former GDR): Suhl, Thuringia & $1982-1983$ & Ruminants & 156 & CFT & $\begin{array}{l}{[92]} \\
{[40]}\end{array}$ \\
\hline $\begin{array}{l}\text { BG: Knezja, Brenitza, Lazarovo, Enitza } \\
\text { (Vratza district) }\end{array}$ & 1984 & Ruminants & 725 & CFT & [23] \\
\hline BG: Pavlikeni (Veliko Tarnovo district) & 1985 & Ruminants & 544 & CFT & [23] \\
\hline FR: (Martigues, Bouches du Rhône) & $1990-1995$ & Sheep & 289 & IFA & [1] \\
\hline DE: Berlin & 1992 & Sheep & 80 & CFT & {$[93,94]$} \\
\hline BG: Panagjuriste (Pazardjik district) & $1992-1995$ & Livestock & $>1,000$ & CFT & $\begin{array}{l}\text { [23] (for 1993); } \\
\text { [29] (for 1992, } \\
1993 \text { and 1995) }\end{array}$ \\
\hline DE: Düsseldorf, Nordrhine-Westphalia & 1994 & Sheep & $>18$ & CFT & [95] \\
\hline $\begin{array}{l}\text { BG: Sopot (Plovdiv district), Troyan } \\
\text { (Lovech district), Blagoevgrad, Pleven }\end{array}$ & $1996-2000$ & Livestock & NA & CFT & [23] \\
\hline FR: Briançon (Hautes Alpes) & 1996 & Sheep & 29 & IFA & [1] \\
\hline DE: Rollshausen, county of Lohra, Hesse & 1996 & Sheep & 56 & ELISA & {$[96,97]$} \\
\hline DE: Baden-Württemberg, not specified & 1997 & Fallow deer & 12 & NA & [37] \\
\hline DE: Dortmund, Nordrhine-Westphalia & 1999 & Sheep (manure) & 82 & NA & [1] \\
\hline FR: Montoison (Drôme) & 2000 & Goat (manure) & 10 & NA & [1] \\
\hline FR: Montoison (Drôme) & 2000 & Sheep (manure) & 5 & IFA & [1] \\
\hline $\begin{array}{l}\text { DE: Hochsauerlandkreis Nordrhine- } \\
\text { Westphalia, Waldeck-Franckenberg, Hesse }\end{array}$ & $2000-2001$ & Sheep & 75 & NA & [98] \\
\hline DE: Munich, Bavaria & 2001 & Sheep & 3 & NA & [98] \\
\hline BG: Etropole (Sofia district) & 2002 & Livestock & 121 & CFT & [23] \\
\hline FR: Chamonix Valley & 2002 & Sheep & 88 & IFA & [1] \\
\hline DE: Soest, Nordrhine-Westphalia & 2003 & Sheep & 299 & ELISA & [99] \\
\hline DE: Baden-Württemberg & 2003 & Cattle & 8 & NA & [100] \\
\hline BG: Botevgrad (Sofia district) & 2004 & Sheep, goats & 220 & IFA, CFT & $\begin{array}{l}{[32]} \\
{[23]} \\
\end{array}$ \\
\hline DE: Jena, Thuringia & 2005 & Sheep & 331 & ELISA & [101] \\
\hline $\begin{array}{l}\text { NL: mainly Noord-Brabant, Limburg, } \\
\text { Gelderland, NL }\end{array}$ & $2007-10$ & Dairy goats & $4,026^{a}$ & $\begin{array}{l}\text { IFA, CFT, ELISA, } \\
\text { PCR }\end{array}$ & {$[14-17]$} \\
\hline FR: Florac & 2007 & Sheep & 18 & NA & [25] \\
\hline FR: Hautes-Alpes & 2008 & Livestock & 12 & IFA & {$[26]$} \\
\hline DE: Lahn-Dill-Kreis, Hesse & 2008 & Sheep & 246 & NA & {$[102,103]$} \\
\hline DE: Aschaffenburg, Bavaria & 2008 & Sheep & 256 & $\mathrm{NA}$ & [102] \\
\hline DE: Paderborn, Westphalia & 2009 & Sheep & 5 & NA & [104] \\
\hline DE: Baden-Würtemberg & 2010 & NA & 235 & NA & [2] \\
\hline
\end{tabular}

BG: Bulgaria; CFT: complement fixation test; DE: Germany; ELISA: enzyme-linked immune-sorbent assay; FR: France; GDR: German Democratic Republic; IFA: indirect immunofluorescence assay; NA: Information not available or not specified; NL: Netherlands; PCR: Polymerase chain reaction.

a Includes 168 in 2007, 1,000 in 2008, 2,354 in 2009 and 504 in 2010. 
EC, as amended by Decision 2003/534/EC). Earlier reports of sporadic cases and outbreaks in these countries are available (Table 3 ).

During the period from 1984 to 2006 , the number of serologically confirmed cases per outbreak varied between 121 and more than 1,000 in Bulgaria [23]. Outbreaks in Bulgaria have occurred in various geographic areas (including Knezja, Sopot, Etropole, Troyan, Botevgrad) and over several years in a single area (e.g. Panagyurische) (Table 3).

The average annual incidence of $Q$ fever in Germany during 1979 to 1999 was estimated to be 1.1 (o.8-4.1) per million [19]. An estimated total of 200 to 400 human cases were registered as sporadic cases or outbreaks each year from 2007 to 2009 in Germany in the regions of Jena (Thuringia), Göppingen (Baden-Württemberg), Lahn-Dill Kreis (Hesse) and Aschaffenburg (Bavaria), and most frequently from Baden-Württemberg, Hesse and Bavaria [24]. During the period from 2004 to 2009, no significant increase in the number of cases was seen in North Rhine-Westphalia or Lower Saxony, which neighbour the Netherlands.

In the period from 1990 to 1995, an outbreak of Q fever was reported in France (Martigues, near Marseille and Aix-en-Provence, Bouches du Rhône), with 289 human cases [1]. A further 29 cases were reported (Briançon, Hautes Alpes) in 1996 and 15 (Montoison, Drôme) in 2000 [1]. Subsequently, outbreaks have been reported in the Chamonix valley, Haute Savoie in 2002, with 88 human cases [1], in Florac, Lozère in 2007, with 18 cases [25] and in Hautes-Alpes in 2008, with 12 cases [26] (Table 3).

In the Netherlands, annual notifications ranged between one and 32 human cases between 1978 and 2006, with the majority of cases occurring among people with occupational risk (e.g. persons in close contact with farmed animals, including farmers and veterinarians). From May 2007, however, there was a considerable increase in notification of human $\mathrm{Q}$ fever cases in the province of Noord-Brabant [27]. C. burnetii infection was identified in more than 160 patients presenting during May and June $2007[14,16,17,28]$. In $2008,1,000$ human cases were identified, with a hospitalisation rate of $20.9 \%$ [16]. In 2009, 2,354 new Q fever cases were registered in the national infectious disease notification database, with a hospitalisation rate of $19.7 \%$, comparable to the situation in 2008 [16]. In 2010, 504 cases were notified, of which 406 had a known day of onset of illness in 2010, indicating that the peak of the epidemic had been reached in 2009. In this epidemic, most cases were found in the province of Noord-Brabant (Table 3).

\section{Potential risk factors}

Proximity to infected animals

Animal proximity and contact with infected animals and/or their contaminated products (e.g. birth products) have been identified as important risk factors for humans in each of the four countries. In most outbreaks, there are reports of spill-over of infection to humans from infected domestic small ruminants, i.e. goats $[29,30]$ or sheep [31]. In contrast, there is no evidence in support of a major contribution of cattle in the history of $\mathrm{Q}$ fever in humans in the four study countries. In the Netherlands, living close $(<2 \mathrm{~km})$ to a large dairy goat farm where an abortion wave due to $C$. burnetii had occurred was identified as the most important risk factor for human $\mathrm{Q}$ fever [30]. The movement of domestic small ruminants through settlements has been linked with a number of outbreaks in Bulgaria (Botevgrad in 2004 [32], Panagyurische in 1992, 1993 and 1995, Kneyzha in 1984 and Pavlikeni in 1985 [29]) and France (Chamonix valley [33]). Sheep shearing is considered an important risk factor in Germany. Infected tick faeces is present in the wool, leading to contamination of dust, and the potential for further spread of the agent through storms and winds [19,31,34]. In some human outbreaks, involvement of other host species has been noted, e.g. contact with contaminated pigeon faeces [35], cats [36] or fallow deer [37].

The outbreaks in Germany and the Netherlands have been associated with urban areas. A large human Q fever cluster in an urban area in the Netherlands in 2008 was clearly linked to a dairy goat farm with more than 400 adult goats. On this farm, an abortion wave due to $C$. burnetii was confirmed, starting a few weeks before the first human cases were seen [30]. In Bulgaria, a number of human outbreaks have involved people without any known occupational hazards, such as employment or place of residence, with agriculture or the processing of animal products [30]. In the Botevgrad outbreak, most patients had no association with goats, sheep or cattle [2]. Proximity should not be seen in isolation, since the geography and landscape may also play a role in the spread of infection [38]. In Bulgaria, France, and Germany, most of the recent 25 outbreaks have occurred in small towns located in valleys close to mountains or semi-mountainous areas with meadows or in regions with specific climatic conditions, in particular dry, windy weather, in Bulgaria (Panagyurische, Sopot, Troyan, Etropole), France (Chamonix valley, Florac) and in Germany (Jena, Thuringia; Göppingen, Baden-Württemberg; Lahn-Dill Kreis, Hesse; Aschaffenburg, Bavaria). The outbreak in the Netherlands contrasts with the geographical features being described here although dry windy weather conditions may have facilitated the spread of the bacterium [13].

Management of the farms and husbandry practices Intrinsic farm factors, such as production system and management, are believed to influence the number of 
outbreaks in an area. In the Netherlands, the introduction of a milk quota system for dairy cattle in 1984 stimulated the development of a dairy goat industry. This subsequently led to an increased number of modern dairy goat farms, many in areas of high human population density, with high numbers of dairy goats on a single farm. In Germany, the production system for sheep meat changed to meet the seasonal demand for mutton. The introduction of new methods of production and synchronisation coincided with peaks of human infections during lambing seasons in spring when sheep flocks were released from winter stables. Since the 1950s, there have been substantial changes in livestock production systems in Bulgaria, from extensive systems to industrial systems and development of small farms [23,39], leading to a substantial reduction in sheep ( 8 million in 1990, 3 million in 1997) and an increase in goats $(430,000$ in 1990,1 million in 1997) [29]. Although C. burnetii seroprevalence in farm animals has decreased in Bulgaria in the 2000 s comparing with the 1970 s and 1980 s [23], the prevalence of infection in human risk groups has remained relatively constant (Table 2). Since 1990, there has been a shift in the seasonal presentation of human cases in Bulgaria, concurrent with changes in the seasonal pattern of parturition in goats and sheep [29]. In Bulgaria, cattle herds and sheep flocks tend to be large but are kept separately from the human population, whereas goats are present as multiple small herds within towns. An association between the number of positive animals in a herd and poor management (e.g. introduction of rams of unknown health status for mating, purchase of females of unknown health status, no removing of afterbirth) was noted in Germany [40].

\section{Potential reservoirs of infection in nature}

The presence of a natural reservoir in the environment or in wildlife, and spill-over to farm animals, are often considered pre-requisites for endemicity of $Q$ fever in a geographic region. Based on seroprevalence and/ or strain isolation, there is evidence of $C$. burnetii infection in a wide variety of host species (domestic livestock, domestic pets, wild mammals, birds and ticks) $[23,37,41]$. Evidence of $C$. burnetii infection has been found in domestic dogs (seroprevalence of $13 \%$ ) and cats (26\%) in Germany in a study in 1987 [41]. In Bulgaria, $16.8 \%$ of ixodic ticks collected between 1993 and 2004 were found to be positive by immunofluorescent haemocytic test [20], and 22 to $26 \%$ using other methods [42]. In contrast, low levels of $C$. burnetii DNA in ticks collected between 2006 and2007 have been reported for Thuringia in Germany [43]. Between 2006 and 2010, approximately 3,000 ticks (1,891 questing Ixodes ricinus and 1,086 ticks feeding on pets, wildlife and livestock) were tested for the presence of $C$. burnetii DNA in the Netherlands [44]. All ticks were negative, even from high $Q$ fever incidence areas. Only five ticks from one sheep herd tested Coxiella-positive and herd was not detected positive after resampling three months later.

\section{Control options}

In each of the four countries considered in this review, a range of measures were taken by the competent authorities in response to the disease, as follows:

Measures to increase diagnostic

precision and general awareness:

In the Netherlands, the capability for diagnosis of human $Q$ fever had increased substantially in 2008 and 2009 , as compared to 2007 , the first year of the epidemic $[14,16]$. Increasing familiarity with the presentation of $Q$ fever in people resulted in more-rapid diagnosis of clinical cases and a lower percentage of hospital admissions. The government-funded $Q$ fever network in Germany [45] was able to transfer diagnostic capability, including cultivation techniques, to two human medical laboratories to address an important gap in diagnostic capability. This network was initiated to promote epidemiological work to identify the risks of $Q$ fever for public health, to develop reasonable counter-measures, to conduct basic research and to raise public awareness. The network relies on a 'One Health' approach among physicians, veterinarians, epidemiologists and software developers. Further, efforts have been made to increase case notification (both in humans and farm animals) and to increase awareness among medical doctors, veterinarians and the broader public, with greater emphasis on timely hospitalisation of patients and optimised medication to reduce life threatening sequelae. Case-control studies and intensive testing carried out during and after the outbreaks in France in 2002 [33] and 2007 [25], and in Bulgaria in 2004 [32], provided more detailed information on the status of affected areas and increased general awareness about the disease.

Measures to reduce human exposure and to reduce spill-over:

A range of temporary ad hoc measures have been used including restrictions on visits to infected farms (the Netherlands during 2007-2010 [2,13-15]), limits to human assembly in high-risk areas [2,32] including the closing of schools in Bulgaria during an outbreak in 2004 [32], the stopping of blood donation in affected areas (France in 2002 and 2007, Germany 2005) $[25,31,33]$, the removal of infected herds/flocks from human settlements (in Bulgaria during 2004) [32], and the introduction of a ban on animal movements (all four countries). Further, good farming practice is recommended, as long term universal measures, particularly for manure $[2,13,15,46,47]$, such as covering and natural composting or ploughing of manure so that no aerosolisation of agents is possible, closed composting with $\mathrm{CaO}$ (in the Netherlands) $[46,47]$ or $\mathrm{CaCN}_{2}$ (in France and Germany) [48], and the removal of animal birth and abortion products (all four countries). Other measures have included disinfection of infected premises including paths and general environment of holdings (Bulgaria during 2004) [32], obligatory notification of increased farm animal abortion rate to the local authorities (France, the Netherlands) $[2,12,13]$, the 
potential use of veterinary vaccines (France 2009, the Netherlands 2007-2010) $[13,49,50]$ and the implementation of a farm animal breeding ban (the Netherlands 2007-2010 [2,13]).

In the Dutch outbreak between 2007 and 2010, several counter-measures were introduced, following consideration of both national and international (including EFSA) expert opinion. These measures included the development of notification criteria after which $Q$ fever became a notifiable disease in farmed animals, a ban on animal transport especially from infected farms, visitor bans on infected farms, the promotion of general hygiene measures, the implementation of a safe manure management including prevention of aerosolisation, the introduction of a farm animal vaccination programme for small ruminants, testing of bulk milk (milk collected in large quantities from different dairy animals) using a PCR to identify infected herds, and breeding restrictions. The vaccination programme was initiated in October 2008, following special dispensation of a phase I Q fever vaccine (Coxevac, CEVA), through a voluntary scheme involving dairy sheep and dairy goats on farms with more than 50 goats or sheep, pet zoos and nursing farms in a restricted highrisk zone, an area with radius $45 \mathrm{~km}$ around the city of Udden. At that time, vaccination was restricted to a limited area, due to a shortage of vaccine. A mandatory vaccination programme was subsequently introduced in an enlarged area including the province of Noord-Brabant, leading to vaccination of dairy sheep and dairy goats prior to 1 January 2010 on farms with more than 50 animals, and on care farms, pet zoos and zoos. Nationwide mandatory vaccination coverage was achieved in 2011, and also included small ruminants attending shows [2]. Culling of more than 50,000 pregnant animals aiming at reducing the shedding of C. brunetii and as a consequence of that, environmental contamination trying to reduce human exposure in 2010, was undertaken on PCR bulk tank milk positive farms followed by a programme of repopulation with fully vaccinated animals originating only from PCR bulk tank milk negative farms. Compensation schemes were available for the farmers when culling was ordered $[13,51]$. In the Netherlands, a human vaccine (the Australian human vaccine Q-VAX, currently not registered in Europe) was made available in July 2010 to people at risk from chronic $Q$ fever, such as patients with cardiac valve disease, aortic aneurisms, and vascular prostheses [52]. The human vaccination programme commenced in January 2011, after the Q fever outbreak in the Netherlands had subsided [14].

\section{Discussion}

This review presents information on the presence of C. burnetii during the period from 1982 to 2010 in countries of Europe that differ greatly in terms of animal and human population, livestock density and production systems. The regional presentation of $Q$ fever varies considerably, based on several data sources. Non-standardised serological data are available about the presence of $C$. burnetii in various domestic animal species and wildlife. In addition, severe human outbreaks or epidemic waves have also been described. Information from these four countries illustrates the epidemiological variability of human outbreaks and the considerable range of risk factors involved. Nevertheless, some general patterns emerge which are discussed below, together with areas of uncertainty where further research is justified.

Domestic ruminants are considered the primary reservoir for $C$. burnetii $[1,53]$. Human cases and outbreaks are attributed to infection in sheep (in Germany) and goats (Bulgaria, France, the Netherlands), but not cattle. We found no evidence in support of a major contribution of cattle in the history of $Q$ fever in the four study countries, even though $C$. burnetii infection can also lead to shedding and abortion in cattle [54]. Abortion in cattle is a less prominent feature of infection compared to sheep and goats $[1,49,55]$. We speculate that the prominent role of sheep and goats as reservoirs of infection during human outbreaks may be related to the highly seasonal nature of their reproduction cycle, to the larger herd sizes in these species, to differences in management and housing between these species, to the relative importance of shedding and abortions after C. burnetii infection, and possibly to species-related differences in the virulence for humans of $C$. burnetii.

Abortions in C. burnetii-infected domestic ruminants are accompanied by massive excretion of the bacteria and spread into the environment. This is the most important excretion route of C. burnetii, as up to 109 organisms are excreted per gram of placenta tissue [56]. The level of excretion is believed less following the birth of healthy calves, kids or lambs from infected animals [48]. C. burnetii has also been detected in faeces, vaginal mucus and milk of infected domestic ruminants [57,58]. In goat herds, in both aborting and non-aborting goats, $C$. burnetii DNA has been detected in faeces, vaginal mucus and/or milk [58]. Also, in cattle, variable excretion via faeces, vaginal mucus and milk has been reported, sometimes independent of an abortion history. Sixty-five per cent of cows seem to shed $C$. burnetii by only one of these routes, with few cows excreting $C$. burnetii by all three routes [55]. Comparison of the three excretion routes in cattle, goats and sheep showed that milk shedding is more frequent in cattle and goats. Ewes shed more and for a longer duration in vaginal mucus than goats [1]. Sheep and goats can both shed $C$. burnetii in subsequent pregnancies $[59,60]$.

An elevated seroprevalence in domestic ruminants has been noted in areas with human outbreaks. In the outbreaks in Etropole (2002) and Botevgrad (2004) in Bulgaria, herd-level seroprevalence ranged from $11.6 \%$ to $33.0 \%$ (cattle), from $46.6 \%$ to $59.5 \%$ (sheep) and from 63.3 to almost $100 \%$ (goats). In contrast, median herd-level countrywide prevalence was 7.1 to $21.7 \%$ [23]. Of 26 sheep, goat and cattle flocks/herds located 
within $5 \mathrm{~km}$ of an outbreak in Florac (2007) France, 11 were enzyme-linked immunosorbent assay (ELISA)positive [25,61]. An increase in seroprevalence among ruminant herds in known areas of risk may assist in predicting outbreaks in humans.

Genetic differences of $C$. burnetii strains have been discussed as one reason for differing pathogenicities in guinea pigs and mice when infected with different isolates from domestic ruminants [23,62]. However, it is not clear whether there is a correlation between multilocus variable-number tandem repeat analysis (MLVA) types and virulence. The Dutch outbreak was the first outbreak where detailed investigations were conducted on the genotype of $C$. burnetii. A single MLVA type appeared responsible for the majority of the $C$. burnetii-related abortion on goat farms in the Netherlands [51]. Little is known of MLVA types from other outbreaks. The identified limited genetic diversity in the Netherlands precludes investigation of local transmission pathways and molecular typing methods have to be developed further, including high-resolution genotyping based on whole genome sequencing, to match human, veterinary, and environmental samples.

In the four countries under study, as elsewhere in the world $[1,8]$, there is evidence of widespread exposure to $C$. burnetii in both the human and domestic ruminant populations. However, clinical cases of $Q$ fever in people are generally very rare. As reflected in this review, outbreaks are generally associated with a range of risk factors, including close contact between people and small ruminants, and events (such as abortions) leading to increased shedding of $C$. burnetii in these small ruminant populations. Other factors may also be important, but are not well understood. During the Dutch outbreak, for example, it was suggested that the human population in the Netherlands was more susceptible to disease because seroprevalence was low, the number of animals in the farms was high with consequent assumption of the amount of manure and lochia, with potential of human exposure. The change in management of animals from industrial-type housing to small private farms in Bulgaria was a hypothesis for the observed variation of within-herd prevalence over a period. However, it seems likely that $C$. burnetii infection can be maintained in a wide range of husbandry systems in all four countries. The Dutch outbreak developed in a geographic area without historic $Q$ fever problems. This is different to the recognised pattern, in Bulgaria, France and Germany, of outbreak occurrence and re-occurrence in specific geographic localities. Although a windborne spread appears to have played an important role in the transmission of infection from animals to people, in all four countries. More work is needed to develop a systematic understanding of the risk factors involved and their interactions.

The control measures pursued by different countries were in general targeted at reducing human exposure and spill-over from animal populations to humans. In each of these countries, human cases have generally been linked to exposure to aerosols with high numbers of $C$. burnetii excreted during parturition by infected ruminants. During outbreaks in Bulgaria and France, strategies for prevention and control of $Q$ fever in people were designed, cognisant of the influence of specific conditions [32] on transmission of infection, such as dry weather, wind direction, and the location of human population at risk in a valley with hillside pastures [26]. The main challenges on the control of the disease are linked to the sustainability of measures such as culling or reproduction bans but also the persistence of infection in both animals and the environment. Furthermore there is limited data regarding the effectiveness of different control measures.

Measures that can be applied on-farm to reduce spillover from farm animals to humans are limited to vaccination and on-farm hygienic measures. There is evidence in support of vaccination being effective in preventing abortions in small ruminants and in reducing the shedding of $C$. burnetii $[1,63]$, although it has been suggested that this must be sustained for at least several years $[64,65]$. Outbreak vaccination, i.e. vaccinating herds that already are infected $[64,66]$ or otherwise under high infection pressure [65], are each believed to be less effective. The risk of $Q$ fever outbreaks and possibly other zoonotic diseases remains high in relatively small areas such as the province of Noord-Brabant in the Netherlands, with large populations of people (2.4 million) and animals (6.4 million). There remains uncertainty about the effectiveness of control measures other than vaccination. Farm hygienic measurements (such as manure sterilisation/composting and management, disinfection of the paths and ways to the pastures, indoor housing during lambing season, air-filter systems in housings and movement controls) are likely to have limited effectiveness in reducing infection risk. There is incomplete information about either $C$. burnetii survival times in manure and in the general environment, or the period during which surviving bacteria remain a threat for public health. Reports suppose a long lasting period of survival and infectivity, possibly up to two to three years or more $[3,67]$. Based on information from the Netherlands outbreak between 2007 and 2010, however, we did not find evidence for this. There was a rapid decrease in human cases in 2010, immediately following the last of the abortion storms that occurred in goats in 2009. Similarly, the various outbreaks in Germany and France were single events related to human exposure to small ruminants. In each situation, human cases were limited in time. The inevitable contamination of the environment did not seem to cause an elevation of human cases for a longer period of time.

Concerning the Dutch $\mathrm{Q}$ fever outbreak during the period between 2007 and 2010, at least some facts can be ascertained. Seroprevalence among the general population increased from $2.4 \%$ before the first outbreak in 2007 to around $12 \%$ in the high incidence area 
in 2009 (Table 2). During the same period, the number of notified acute $Q$ fever patients decreased from 2,354 in 2009 to 504 in 2010 [14]. Several veterinary measures were implemented in the Netherlands concurrently, making it impossible to establish the relative contribution of each (vaccination, culling, on-farm hygienic measures, or other factors) to this decline in incidence. It should also be noted that the prevalence of $C$. burnetii in an infected herd usually declines over time even if no countermeasures are taken, probably caused by a 'natural' immunisation of susceptible animals (Table 1). However, meaningful scientific data are still missing. The development of a protective and safe vaccine for animals is strongly recommended.

Eradication of $Q$ fever from a herd is not currently straightforward for a range of reasons, including chronic infection in a small number of animals (personal communication, R. Van den Brom, September 2012), the presence of shedding, but test-negative, animals, and the potential for recurrent shedding of the agent $[58,59,68]$. Reduction of excretion has been reported using a phase $1 C$. burnetii vaccine for animals, however, this could be affected by herd infection status and the timing of vaccination [63-66]. To minimise human health risks, vaccination of animals may need to be conducted in combination with repeated testing, for example using a PCR on individual milk samples, and the culling of infected animals $[69,55,57,64]$.

In each of the countries under investigation, seroprevalence measured at the individual animal level was lower than herd seroprevalence. In other words, in each herd only a relatively low number of animals seroconverted after contact with $C$. burnetii. This result is somewhat surprising, given the known high rate of infectivity of $C$. burnetii in ruminant populations (Table 1). When $C$. burnetii is introduced on a farm with few pregnant animals (goats), seroconversion is expected mainly in these animals, following birth, because of the strong tropism of the pathogen for placenta trophoblasts [70], although C. burnetii is found everywhere in the surroundings. Low within-herd sero-prevalence is also seen with other infections where pathogens also may survive readily outside the host, such as paratuberculosis [71]. The role of differences in individual resistance and cell-mediated response should also be explored.

Epidemiological studies on C. burnetii infection and $\mathrm{Q}$ fever in humans need to be interpreted with care, given differences in both the underlying epidemiological conditions and the study designs used (including sample size, target groups, serological test, serological cut-off and study purpose). The lack of standardisation between studies was an important constraint in the current work. In most cases, studies have been conducted with biased sub-populations of people, including those with a known risk and elevated levels of $C$. burnetii in animal populations, such as for example, people in the outbreak areas and with potentially compromised health. For these reasons, it can be difficult to draw meaningful conclusions about the underlying seroprevalence of $C$. burnetii in people in these four countries. Further, observed differences over time are difficult to explain, such as the extremely high prevalence in a risk group in the Netherlands in the $1980 \mathrm{~s}$ in comparison to the much lower prevalence in humans in outbreak area in recent years (February 2006-June 2007) [2,72]. This latter observation may, in part at least, reflect a lack of specificity in earlier testing methods, which relied on in-house immunofluorescent assays and application of a low cut-off for positivity. However, seroprevalence in occupational risk groups in the 1980 s and during the 2007 to 2010 outbreak in the Netherlands were comparable [14].

A number of conclusions can be drawn from this review of $C$. burnetii infection and $Q$ fever in people and domestic ruminants in four countries in Europe. In all outbreaks, human contact with sheep and goats, rather than cattle, has been a consistent feature and the most likely source of $C$. burnetii infection. As yet, however, there is insufficient information to enable early prediction of large outbreaks of $Q$ fever in people. Mandatory notification of $Q$ fever in humans is an important surveillance strategy, and has been recommended previously [73], but is yet to be implemented in many countries in the EU [12]. Reporting of C. burnetii-related abortion cases in animals is compulsory in some countries $[2,12]$, but interventions by authorities are typically not initiated in sporadic cases. A more systematic use of such data for analysing the dynamics and seasonality of cases and to inform animal owners to take voluntary precautions should be considered. The cooperation and flow of information between veterinary and medical professionals, and vice versa, is critical $[2,73]$, and initiatives to build strong links between authorities involved in the monitoring and control of zoonoses similar to the Human Animal Infection Risk and Surveillance (HAIRS) group in England and Wales [74] are recommended. Much remains unclear about the transmission of $\mathrm{C}$ burnetii from animals to humans, about means for early detection of increased risk of outbreaks, the effectiveness of veterinary control measures, and about the best follow-up strategy in territories with repeated outbreaks over several years. Future research should focus on these topics.

\section{Acknowledgements}

This review was conducted as part of an opinion on $Q$ fever by the Animal Health and Welfare (AHAW) Panel of the European Food Safety Authority. The authors acknowledge the input from panel members during the development of this review.

\section{Conflict of interest}

None. 


\section{References}

1. Arricau-Bouvery N, Rodolakis A. Is $Q$ fever an emerging or reemerging zoonosis? Vet Res. 2005;36(3):327-49. http://dx.doi. org/10.1051/vetres:2005010 PMid:15845229

2. European Food Safety Authority (EFSA). Scientific opinion on $Q$ fever. EFSA Journal. 2010;8(5):1595.

3. World Organisation for Animal Health (OIE). 2010 Q fever. In: Manual of Diagnostic Tests and Vaccines for Terrestrial Animals. Paris: OIE; 2010. Available from: http://www.oie. int/fileadmin/Home/eng/Health_standards/tahm/2.01.12_QFEVER.pdf

4. Derrick EH. “Q” fever a new fever entity: clinical features, diagnosis, and laboratory investigation. Rev Infect Dis. 1983;5(4):790-800. http://dx.doi.org/10.1093/clinids/5.4.790 PMid:6622891

5. Davis GE, Cox HR. A filter-passing infectious agent isolated from ticks. I. Isolation from Dermacentor andersoni, reactions in animals, and filtration experiments. Public Health Reports. 1938;53(52):2259-61. http://dx.doi.org/10.2307/4582746

6. Imhauser K. Viruspneumonien: Q-Fieber und Virusgrippe. Klin Wochenschr. 1949;27(21-22):353-360. German. http://dx.doi. org/10.1007/BFo1479375

7. Westra SA, Lopes Cardozo E, ten Berg J. [The first cases of Q fever in the Netherlands]. Ned Tijdschr Geneeskd. 1958;102(2):69-72. Dutch. PMid:13517338

8. Maurin M, Raoult D. Q Fever. Clin Microbiol Rev. 1999;12(4):518-33. PMid:10515901 PMCid:88923

9. Council of the European Union. Commission Decision 2008/426/EC of 28 April 2008 amending Decision 2002/253/EC laying down case definitions for reporting communicable diseases to the Community network under Decision No 2119/98/EC of the European Parliament and of the Council. Official Journal of the European Union. Luxembourg: Publications Office of the European Union. 18.6.2008:L159:46-90.

10. Lang GH. Coxiellosis (Q fever) in animals. In: Marrie TJ, editors. The Diseases vol. 1. Boca Raton: CRC Press; 1990. p. 23-48.

11. Guatteo R, Seegers H, Taurel AF, Joly A, Beaudeau F. Prevalence of Coxiella burnetii infection in domestic ruminants: A critical review. Vet Microbiol. 2011;149(1-2):1-16. http://dx.doi. org/10.1016/j.vetmic.2010.10.007 PMid:21115308

12. Sidi-Boumedine K, Rousset E, Henning K, Ziller M, Niemczuck K, Roest HIJ, et al. Development of harmonised schemes for the monitoring and reporting of $Q$ Fever in animals in the European Union. EFSA Scientific Report on question No EFSA-Q-2009-00511, 2010. 48 pp. Available from: http://www. efsa.europa.eu/en/supporting/doc/48e.pdf

13. Roest HI, Tilburg JJ, van der Hoek W, Vellema P, van Zijderveld FG, Klaassen $\mathrm{CH}$, et al. The $\mathrm{Q}$ fever epidemic in The Netherlands: history, onset, response and reflection. Epidemiol Infect. 2011;139(1):1-12. http://dx.doi.org/10.1017/ So950268810002268 PMid:20920383

14. van der Hoek W. The 2007-2010 Q fever epidemic in the Netherlands: risk factors and risk groups [PhD thesis]. Utrecht: Utrecht University; 2012. ISBN: 978-90-6464565-5. Available from: http://igitur-archive.library.uu.nl/ dissertations/2012-0607-200454/vanderhoek.pdf

15. van den Brom R, Vellema P. Q fever outbreaks in small ruminants and people in the Netherlands. Small Ruminant Res. 2009;86(1-3):74-9. http://dx.doi.org/10.1016/j. smallrumres.2009.09.022

16. van der Hoek W, Dijstra F, Wijers N, Rietveld A, Wijkmans CJ, van Steenbergen JE, et al. [Three years of $Q$ fever in the Netherlands: faster diagnosis]. Ned Tijdschr Geneeskd. 2010;154:A1845. Dutch. PMid:20619049

17. Schimmer B, Dijkstra F, Vellema P, Schneeberger PM, Hackert V, ter Schegget R, et al. Sustained intensive transmission of $Q$ fever in the south of the Netherlands. Euro Surveill. 2009;14(19):pii19210. Available from: http://www. eurosurveillance.org/ViewArticle.aspx?Articleld=19210

18. Serbezov V, Shishmanov E, Aleksandrov E, Novkirishki V. [Rickettsioses in Bulgaria and other Balkan countries]. Danov CG, editor. Plovdiv: Christo G. Domov, 1973, p. 223. Bulgarian.

19. Hellenbrand W, Breuer T, Petersen L. Changing epidemiology of Q fever in Germany, 1947-1999. Emerg Infect Dis. 2001;7(5):789-96. PMid:11747689 PMCid:2631891

20. Woernle H and Müller K, 1986. Q-Fiebr beim Rind: Vorkommen, Bekämpfung mit Hilfe der Impfung und / oder antibiotischen Behandlung. Tierärztl. Umschau, 41, 201-212. German.

21. Krauss H, Schmeer N, Schiefer H G. Epidemiology and significance of Q fever in the Federal Republic of Germany. Zentralbl Bakteriol Mikrobiol Hyg A.1987;267(1): 42-50.
22. Chartier C, Beziaud E, Buzoni-Gatel D, Bout D, Calamel $M$, Russo $P$, et al. Enquête séro-épidémiologique sur les avortements infectieux des caprins en région PoitouCharentes. Rev Med Vet (Toulouse). 1997;148(6):489-96 French.

23. Martinov S. Contemporary state of the problem $\mathrm{Q}$ fever in Bulgaria. Biotechnol Biotec Eq. 2007;21(3):353-61.

24. Conraths F, Bernard H, Henning K, Kramer M, Neubauer H. Q-Fieber: Zur Situation in Deutschland und den Niederlanden. Tierarztl Umsch. 2010;65:152-9. German.

25. Institut de Veille Sanitaire (INVS). Investigation of a Q fever outbreak in a rural area of France. Paris:INVS.2009. French. Available from:http://www.invs.sante.fr/publications/2009/ fievreq_florac2007/index.html

26. Institut de Veille Sanitaire (INVS). Investigation d'une épidémie de fièvre $Q$ dans le department des Hautes-Alpes. Avril-Août 2008. Paris: INVS. 2010. French. Available from http://www. invs.sante.fr/publications/2010/fievre_q_hautes_alpes_2008/ rapport_fievre_q_hautes_alpes_2008.pdf

27. Van Steenbergen JE, Morroy G, Groot CA, Ruikes FG, Marcelis JH, Speelman P. [An outbreak of Q fever in The Netherlands-possible link to goats]. Ned Tijdschr Geneeskd. 2007;151(36):1998-2003. Dutch. PMid:17953175

28. Schimmer B, Morroy G, Dijkstra F, Schneeberger PM, Weers Pothoff $G$, Timen A, et al. Large ongoing $Q$ fever outbreak in the south of The Netherlands. Euro Surveill. 2008;13(31): pii=18939. Available from: http://www.eurosurveillance.org/ ViewArticle.aspx?Articleld=18939

29. Serbezov V, Kazár J, Novkirishki V, Gatcheva N, Kovácová E, Voynova V. Q Fever in Bulgaria and Slovakia. Emerg Infect Dis.1999;5(3):388-94. http://dx.doi.org/10.3201/ eid0503.990309 PMid:10341175 PMCid:2640784

30. Schimmer B, Ter Schegget R, Wegdam M, Züchner L, de Bruin $A$, Schneeberger PM, et al. The use of a geographic information system to identify a dairy goat farm as the most likely source of an urban Q fever outbreak. BMC Infect Dis. 2010;10:69. http://dx.doi.org/10.1186/1471-2334-10-69 PMid:20230650 PMCid:2848044

31. Hellenbrand W, Schöneberg I, Pfaff G, Kramer M, Steng G, Reintjes $R$, et al. [The relevance of Coxiella burnetii infections in animals for $\mathrm{Q}$ fever in humans - measures for prevention and control]. Tierarztl Prax Ausg G Grosstiere Nutztiere. 2005;33(1):5-11. German.

32. Panaiotov S, Ciccozzi M, Brankova N, Levterova V, MitovaTiholova M, Amicosante M, et al. An outbreak of Q fever in Bulgaria. Ann Ist Super Sanita. 2009;45(1):83-6. PMid:19567983

33. Institut de Veille Sanitaire (INVS). Epidémie de fièvre Q dans la vallée de Chamonix (Haute-Savoie) Juin-septembre 2002. Paris: INVS. 2005. French. Available from: http://www.invs.sante.fr/ publications/2005/fievre_q_chamonix/rapport_fievre_q.pdf

34. Schulz J, Runge M, Schröder C, Ganter M, Hartung J. [Detection of Coxiella burnetii in the air of a sheep barn during shearing]. Dtsch Tierarztl Wochenschr. 2005;112(12):470-2. PMid:16425634

35. Stein A, Raoult D. Q fever during pregnancy: A public health problem in southern France. Clin Infect Dis. 1998;27(3):592-6. http://dx.doi.org/10.1086/514698

36. Caron F, Meurice JC, Ingrand P, Bourgoin A, Masson P, Roblot $P$, et al. Acute $Q$ fever pneumonia - A review of 80 hospitalized patients. Chest. 1998:114(3):808-13. http://dx.doi.org/10.1378/ chest.114.3.808 PMid:9743171

37. Robert Koch Institute (RKI). Ein Q-Fieber Ausbruch durch eine infizierte Damwildherde. Epidemiologisches Bulletin 1997;36:249-250. German

38. van der Hoek W, Hunink J, Vellema P, Droogers P. Q fever in The Netherlands: the role of local environmental conditions. Int ] Environ Health Res. 2011;21(6):441-51. http://dx.doi.org/10.108 o/09603123.2011.574270 PMid:21563011

39. Martinov SP. [Studies on some biological, morphological and immunological properties of Coxiella burnetii, the state and the peculiarities of the natural and the agricultural foci of $Q$ fever in Bulgaria]. [PhD thesis], Sofia:2006. Bulgarian.

40. Kramer M. Epizootiologisch-epidemiologische Untersuchungsprogramme von potentiellen Naturherdinfektionen am Beispiel des Q-Fiebers im Bezirk Suhl. Leipzig, 1990. German.

41. Werth D, Schmeer N, Müller HP, Karo M, Krauss H. Nahweis von Antikörpern gegen Chlamydia psittaci und Coxiella burnetii bei Hunden und Katzen: Vergleich zwischen Enzymimmuntest, Immunperoxidase-Technik, Komplementbindungsreaktion und Agargelpräzipitationstest. [Demonstration of antibodies against Chlamydia psittaci and Coxiella burnetii in dogs and cats: comparison of the enzyme immunoassay, immunoperoxidase technic, complement fixation test and 
agar gel precipitation test]. Zentralbl Veterinarmed B. 1987;34(3):165-76. German. PMid:3113133

42. Georgieva G. [Ixodid ticks as vectors of rickettsiae in Bulgaria]. [PhD thesis].Sofia: Military Medical Institute; 1984. Bulgarian.

43. Hildebrandt A, Straube E, Neubauer H, Schmoock G. Coxiella burnetii and coinfections in Ixodes ricinus ticks in central Germany. Vector Borne Zoonotic Dis. 2011;11(8):1205-7. http:// dx.doi.org/10.1089/vbz.2010.0180 PMid:21142964

44. Sprong H, Tijsse-Klasen E, Langelaar M, De Bruin A, Fonville $M$, Gassner F, et al. Prevalence of Coxiella burnetii in ticks after a large outbreak of $Q$ fever. Zoonoses Public Health. 2012;59(1):69-75.

http://dx.doi.org/10.1111/j.1863-2378.2011.01421.x

PMid:21824373

45. Friedrich-Loeffler-Institut (FLI)., [Investigation of molecular pathogenesis of Q-fever and its application in diagnostics and epidemiology in Germany (Network Q-Fever)]. FLI. German. [Accessed: 21 Feb 2012]. Available from http://www.fli.bund. $\mathrm{de} / \mathrm{de} /$ startseite/institute/institut-fuer-bakterielle-infektionen und-zoonosen/projekte/bmbf-verbundprojekt-q-fieber.html

46. Vellema P, van den Brom R, Dercksen D P, Moll L, Roest $\mathrm{H}$ J. Research in relation to the approach of $Q$ fever in the Netherlands. Proceedings of Q-fever conference; 2010 Feb; Breda, the Netherlands. PMCid:2848044

47. VWA, 2009. Opinion of the Director of the Office for Risk Assessment of the VWA, on the risk of $Q$ fever related to manure, The Hague, The Netherlands.

48. Arricau-Bouvery N, Souriau A, Moutoussamy A, Ladenise K, Rodolakis A. Étude de l'excrétion de Coxiella burnetii dans un modèle expérimental caprin et décontamination des lisiers par la cyanamide calcique. Renc Rech Ruminants. 2001;8:153-6. French.

49. Rodolakis A. Q Fever in dairy animals. 2009. Ann N Y Acad Sci. 1166:90-3. http://dx.doi.org/10.1111/j.1749-6632.2009.04511.x PMid:19538267

50. Hermans MH, Huijsmans CR, Schellekens JJ, Savelkoul PH, Wever PC.. Coxiella burnetii DNA in goat milk after vaccination with Coxevac $囚$. Vaccine. 2011;29(15):2653-6. http://dx.doi. org/10.1016/j.vaccine.2011.01.111 PMid:21320538

51. Roest HI, Ruuls RC, Tilburg JJ, Nabuurs-Franssen MH, Klaassen $\mathrm{CH}$, Vellema $\mathrm{P}$, et al. Molecular epidemiology of Coxiella burnetii from ruminants in $\mathrm{Q}$ fever outbreak, The Netherlands. Emerg Infect Dis. 2011;17(4):668-75. http://dx.doi.org/10.3201/ eid1704.101562 PMid:21470457 PMCid:3377418

52. Health Council of the Netherlands. Human vaccination against Q fever; first advisory report. The Hague: Health Council of the Netherlands, 2010. The Hague: Health Council of the Netherlands. 2010. Available from: http://www. gezondheidsraad.nl/en/publications/human-vaccinationagainst-q-fever-first-advisory-report\#a-downloads

53. Angekalis E, Raoult D. Q fever. Vet Microbiol. 2010;140(34):297-309. http://dx.doi.org/10.1016/j.vetmic.2009.07.016 PMid:19875249

54. Woldehiwet Z. Q fever (coxiellosis): epidemiology and pathogenesis. Res Vet Sci. 2004;77(2): 93-100. http://dx.doi. org/10.1016/j.rvSC.2003.09.001 PMid:15196898

55. Guatteo R, Beaudeau F, Berri M, Rodolakis A, Joly A, Seegers H. Shedding routes of Coxiella burnetii in dairy cows: implications for detection and control. Vet Res. 2006;37(6):827-33. http:// dx.doi.org/10.1051/vetres:2006038 PMid:16973121

56. Arricau-Bouvery N, Souriau A, Lechopier P, Rodolakis A. Experimental Coxiella burnetii infection in pregnant goats: excretion routes. Vet Res. 2003;34(4):423-33. http://dx.doi. org/10.1051/vetres:2003017 PMid:12911859

57. Berri M, Laroucau K, Rodolakis A. The detection of Coxiella burnetii from ovine genital swabs, milk and fecal samples by the use of a single touchdown polymerase chain reaction. Vet Microbiol. 2000;72(3-4):285-93. http://dx.doi.org/10.1016/ S0378-1135(99)00178-9

58. Rousset E, Berri M, Durand B, Dufour P, Prigent M, Delcroix $T$, et al. Coxiella burnetii shedding routes and antibody response after outbreaks of $Q$ Fever-induced abortion in dairy goat herds. Appl Environ Microbiol. 2009;75(2):428-33. http://dx.doi.org/10.1128/AEM.00690-08 PMid:19011054 PMCid:2620711

59. Berri M, Souriau A, Crosby M, Rodolakis A. Shedding of Coxiella burnettii in ewes in two pregnancies following an episode of Coxiella abortion in a sheep flock. Vet Microbiol. 2002;85(1):55-60. http://dx.doi.org/10.1016/ S0378-1135(01)00480-1

6o. Berri M, Rousset E, Champion JL, Russo P, Rodolakis A. Goats may experience reproductive failures and shed Coxiella burnetii at two successive parturitions after a $\mathrm{Q}$ fever infection. Res Vet Sci. 2007;83(1):47-52. http://dx.doi.org/10.1016/j. rvsc.2006.11.001 PMid:17187835
61. King LA, Goirand L, Tissot-Dupont H, Giunta B, Giraud C, Colardelle $C$, et al. Outbreak of $Q$ fever, Florac, southern France, spring 2007. Vector Borne Zoonotic Dis. 2011;11(4):3417. http://dx.doi.org/10.1089/vbz.2010.0050 PMid:21395417

62. Martinov S. Studies on mastites in sheep, caused by Coxiella burnetii. Biotechnol Biotec Eq. 2007;21(4):484-90.

63. Hogerwerf L, van den Brom R, Roest HI, Bouma A, Vellema P, Pieterse $M$, et al. Reduction of Coxiella burnetii prevalence by vaccination of goats and sheep, The Netherlands. Emerg Infect Dis. 2011;17(3):379-86. http://dx.doi.org/10.3201/ eid1703.101157 PMid:21392427 PMCid:3166012

64. Astobiza I, Barandika JF, Ruiz-Fons F, Hurtado A, Povedano I, Juste RA, et al. Four-year evaluation of the effect of vaccination against Coxiella burnetii on reduction of animal infection and environmental contamination in a naturally infected dairy sheep flock. Appl Environ Microbiol. 2011;77(20):7405 7. http://dx.doi.org/10.1128/AEM.05530-11 PMid:21856829 PMCid:3194887

65. De Cremoux R, Rousset E, Touratier A, Audusseau G, Nicollet $P$, Ribaud D, et al. Assessment of vaccination by a phase I Coxiella burnetii-inactivated vaccine in goat herds in clinical $Q$ fever situation. FEMS Immunol Med Microbiol. 2012;64(1):1046. http://dx.doi.org/10.1111/j.1574-695X.2011.00892.x PMid:22066485

66. Guatteo R, Seegers H, Joly A, Beaudeau F. Prevention of Coxiella burnetii shedding in infected dairy herds using a phase I C. burnetii inactivated vaccine. Vaccine. 2008;26(34):4320-8. http://dx.doi.org/10.1016/j. vaccine.2008.06.023 PMid:18586060

67. National Agricultural Biosecurity Centre (NABC):Kansas:NABC. 2010. Available from: http://nabc.ksu.edu/

68. De Cremoux R, Rousset E, Touratier A, Audusseau G, Nicollet $P$, Ribaud $D$, et al. Coxiella burnetii vaginal shedding and antibody responses in dairy goat herds in a context of clinical Q fever outbreaks. FEMS Immunol Med Microbiol. 2012;64(1):120-2. http://dx.doi.org/10.1111/j.1574695X.2011.00893.x PMid:22066517

69. Muskens J, van Engelen E, van Maanen C, Bartels C, Lam TJ. Prevalence of Coxiella burnetii infection in Dutch dairy herds based on testing bulk tank milk and individual samples by PCR and ELISA. Vet Rec. 2011;168(3):79. http://dx.doi.org/10.1136/ vr.c6106 PMid:21257587

70. Roest HJ, van Gelderen B, Dinkla A, Frangoulidis D, van Zijderveld F, Rebel J, et al. Q fever in pregnant goats: pathogenesis and excretion of Coxiella burnetii. PLoS One. 2012;7(11):e48949. http://dx.doi.org/10.1371/journal. pone.0048949 PMid:23152826 PMCid:3494687

71. Berry D, Good M, Mullowney P, Cromie AR, More SJ. Genetic variation in serological response to Mycobacterium avium subspecies paratuberculosis and its association with performance in Irish Holstein-Friesian dairy cows. Livestock Sci. 2010;131(1):102-7. http://dx.doi.org/10.1016/j. livsci.2010.03.007

72. Van Duynhoven Y, Schimmer B, van Steenbergen J, van der Hoek W.. The story of human Q fever in the Netherlands. Conference One Health in relation to $Q$ fever, in humans and animals.2010 Feb 25 Breda, the Netherlands.

73. European Centre for Disease Prevention and Control (ECDC). Technical report. Risk Assessment on Q fever, 2010. Stockholm: ECDC. Available from: http://www.ecdc.europa.eu/ en/publications/Publications/1005_TER_Risk_Assessment_ Qfever.pdf

74. Walsh AL, Morgan D. Identifying hazards, assessing the risks. Vet Rec. 2005;157(22):684-7. http://dx.doi.org/10.1136/ vr.157.22.684

75. Rehácek J, Krauss H, Kocianová E, Kovácová E, Hinterberger G, Hanák $\mathrm{P}$, et al. Studies of the prevalence of Coxiella burnetii, the agent of $Q$ fever, in the foothills of the southern Bavarian Forest, Germany. Zentralbl Bakteriol. 1993;278(1):132-8. http:// dx.doi.org/10.1016/S0934-8840(11)80287-2

76. Wittenbrink MM, Gefäller S, Failing K, Bisping W. [The effect of herd factors and animal factors on the detection of complement-binding antibodies against Coxiella burnetii in cattle]. Berl Munch Tierarztl Wochenschr. 1994;107(6):185-91. German. PMid:8067989

77. Sting R, Simmert J, Mandl J, Seemann G, Bay F, Müller KF, et al. [Coxiella burnetii infections and infections with bacteria of the genus Chlamydia in dairy cattle]. Berl Munch Tierarztl Wochenschr. 2000;113(11-12):423-30. German. PMid:11153221

78. Sting R, Kopp J, Mandl J, Seeh C, Seemann G, Kimmig P, et al. [Coxiella burnetii infections in dairy herds with special regard to infections in men]. Berl Munch Tierarztl Wochenschr. 2002;115(9-10):360-5. German. PMid:12357673

79. Agence française de sécurité sanitaire des aliments (AFSSA). Fièvre Q: Rapport sur l'évaluation des risques pour la santé publique et des outils de gestion des risques en élevage de 
ruminants. Comité d'experts spécialisé 'Santé animale', 2004. AFSA; 2004. French. Available from: http://www.afssa.fr/ Documents/SANT-Ra-fievreQ.pdf

8o. Muskens J, Mars MH, Franken P. [Q fever: an overview]. Tijdschr Diergeneeskd. 2007;132(23):912-7. Dutch. PMid:18085174

81. Dubuc-Forfait C, Rousset E, Champion J-L, Marois M, Dufour $P$, Zerhaoui $E$, et al. Demarche d'appreciation du risque d'excretion de Coxiella burnetii dans les troupeaux caprins laitiers dans le sud-est de la France. [Approach for Coxiella burnetii shedding risk assessment in dairy goat herds in south-east of France].Rev Epid San Anim. 2009;55:117-36. French.

82. Chaillon A, Bind JL, Delaval J, Haguenoer K, Besnier JM, Choutet P. [Epidemiological aspects of human $Q$ fever in Indreet-Loire between 2003 and 2005 and comparison with caprine Q fever]. Med Mal Infect. 2008;38(4):215-24. French. http:// dx.doi.org/10.1016/j.medmal.2008.01.010 PMid:18395376

83. Runge M, Ganter M. Q-Fieber. J Verbrauch Lebensm. 2008;3(2):185-9. German. http://dx.doi.org/10.1007/ s00003-008-0333-9

84. Sting R, Breitling N, Oehme R, Kimmig P. [The occurrence of Coxiella burnetii in sheep and ticks of the genus Dermacentor in Baden-Wuerttemberg]. Dtsch Tierarztl Wochenschr. 2004;111(10):390-4. German. PMid:15568636

85. Tissot Dupont H, Raoult D, Brouqui P, Janbon F, Peyramond D, Weiller PJ, et al. Epidemiologic features and clinical presentation of acute $Q$ fever in hospitalized patients: 323 French cases. Am J Med. 1992;93(4):427-34. http://dx.doi. org/10.1016/0002-9343(92)90173-9

86. Thibon M, Villiers V, Souque P, Dautry-Varsat A, Duquesnel $\mathrm{R}$, Ojcius DM. High incidence of Coxiella burnetii markers in a rural population in France. Eur J Epidemiol. 1996;12(5):509-13 http://dx.doi.org/10.1007/BF00144005 PMid:8905314

87. Tissot-Dupont H, Vaillant V, Rey S, Raoult D. Role of sex, age, previous valve lesion, and pregnancy in the clinical expression and outcome of $\mathrm{Q}$ fever after a large outbreak. Clin Infect Dis. 2007;44(2):232-7. http://dx.doi.org/10.1086/510389 PMid:17173223

88. Richardus JH, Donkers A, Dumas AM, Schaap GJ, Akkermans JP, Huisman J, et al. Q fever in the Netherlands: a seroepidemiological survey among human population groups from 1968 to1983. Epidemiol Infect. 1987;98(2):211-9. http:// dx.doi.org/10.1017/S0950268800061938 PMid:3549343 PMCid:2235245

89. Schimmer B, Notermans DW, Harms MG, Reimerink JH, Bakker J, Schneeberger $P$, et al. Low seroprevalence of $Q$ fever in The Netherlands prior to a series of large outbreaks. Epidemiol Infect. 2012;140(1):27-35. http://dx.doi.org/10.1017/ So950268811000136 PMid:21324217

90. van der Hoek W, Meekelenkamp JC, Dijkstra F, Notermans DW, Bom B, Vellema P, et al. Proximity to goat farms and Coxiella burnetii seroprevalence among pregnant women. Emerg Infect Dis. 2011,17(12):2360-3. http://dx.doi.org/10.3201/ eid1712.110738 PMid:22172140 PMCid:3311170

91. Hogema BM, Slot E, Molier M, Schneeberger PM, Hermans MH, van Hannen EJ, et al. Coxiella burnetii infection among blood donors during the 2009 Q fever outbreak in the Netherlands. Transfusion. 2012;52(1):144-50. http://dx.doi.org/10.1111/ j.1537-2995.2011.03250.x PMid:21756265

92. Stelzner A, Kiupel H, Bergmann V, [Coxiella burnetii and Q fever]. Z Klin Med. 1986;41(21):1699-702. German.

93. Schneider T, Jahn HU, Steinhoff D, Guschoreck HM, Liesenfeld O, Mäter-Böhm H, et al. [A Q fever epidemic in Berlin. The epidemiological and clinical aspects]. Dtsch Med Wochenschr. 1993;118(19):689-95. German. http://dx.doi. org/10.1055/s-2008-1059379 PMid:8500412

94. Mölle G, Hentschke J, Laiblin C . [Diagnostic measures on the occasion of a Q-fever epidemic in a sheep flock in Berlin]. Zentralbl Veterinarmed B. 1995;42(7):405-13. German. PMid:8594853

95. Schulze K, Schwalen A, Klein RM, Thomas L, Leschke M, Strauer BE. [A Q fever pneumonia epidemic in Dusseldorf] Pneumologie.1996;50(7):469-73. German. PMid:8927605

96. Lyytikainen O, Ziese T, Schwartlander B, Matzdorff P, Kuhnhen C, Burger C, et al. Outbreak of Q fever in Lohra-Rollshausen, Germany, spring 1996. Euro Surveill. 1997;2(2): pii=136. Available from: http://www.eurosurveillance.org/ViewArticle. aspx?Articleld=136 PMid:12631826

97. Lyytikäinen O, Ziese T, Schwartländer B, Matzdorff P, Kuhnhen C, Jäger C, et al. An outbreak of sheep-associated $Q$ fever in a rural community in Germany. Eur J Epidemiol. 1998;14(2):193-9. http://dx.doi.org/10.1023/A:1007452503863 PMid:9556180
98. Robert Koch Institute (RKI). Ein Q-Fieber Ausbruch im Hochsauerland und Nordhessen. Epidemiologisches Bulletin 2001; 26: 187-189. German.

99. Porten K, Rissland J, Tigges A, Broll S, Hopp W, Lunemann $M$, et al. A super-spreading ewe infects hundreds with Q fever at a farmers' market in Germany. BMC Infect Dis. 2006;6:147. http://dx.doi.org/10.1186/1471-2334-6-147 PMid:17026751 PMCid:1618839

100. Robert Koch Institute (RKI). Ermittlungen zu einem Q-FieberAusbruch in einer Großfamilie. Epidemiologisches Bulletin. 2004;26:205-7. German.

101. Gilsdorf A, Kroh C, Grimm S, Jensen E, Wagner-Wiening C, Alpers K. Large Q fever outbreak due to sheep farming near residential areas, Germany, 2005. Epidemiol Infect. 2008;136(8):1084-7. http://dx.doi.org/10.1017/ So950268807009533 PMid:17892631 PMCid:2870892

102. Robert Koch Institute (RKI). Q-Fieber: Vermehrtes Auftreten im Fruhjahr 2008. Epidemiologisches Bulletin. 2008;25: 199-203. German.

103. Hamann HP, Volmer R, Wimmershof N, Ballmann G, Zschock M. [Q-Fever - Vaccination in Sheep]. Tieraerztl Umsch. 2009;64(4): 188-90. German.

104. Henning K, Hotzel H, Peters M, Welge P, Popps W, Theegarten $D$. [Unanticipated outbreak of $Q$ fever during a study using sheep, and its significance for further projects]. Berl Munch Tierarztl Wochenschr. 2009;122(1-2):13-9. German. PMid:19226931 